\title{
Études/Inuit/Studies
}

\section{BANCROFT HUNT, Norman, 2002 Shamanism in North America, Toronto, Key Porter Books, 232 pages.}

\section{Marilyn Walker}

Volume 28, numéro 2, 2004

Espaces-Lieux-Noms

Spaces-Places-Names

URI : https://id.erudit.org/iderudit/013205ar

DOI : https://doi.org/10.7202/013205ar

Aller au sommaire du numéro

\section{Éditeur(s)}

Association Inuksiutiit Katimajiit Inc.

Centre interuniversitaire d'études et de recherches autochtones (CIÉRA)

\section{ISSN}

0701-1008 (imprimé)

1708-5268 (numérique)

Découvrir la revue

Citer ce compte rendu

Walker, M. (2004). Compte rendu de [BANCROFT HUNT, Norman, 2002

Shamanism in North America, Toronto, Key Porter Books, 232 pages.]

Études/Inuit/Studies, 28(2), 213-216. https://doi.org/10.7202/013205ar d'utilisation que vous pouvez consulter en ligne.

https://apropos.erudit.org/fr/usagers/politique-dutilisation/ 


\title{
Recensions / Book reviews
}

\author{
BANCROFT HUNT, Norman \\ 2002 Shamanism in North America, Toronto, Key Porter Books, 232 pages.
}

Shamanism in North America is a beautiful book to look through and hold. A casual reader will appreciate the clarity of the writing, its uncluttered layout and the generous number of excellent quality, full colour illustrations.

Amongst the book's virtues are its scope and its underlying organizational principle. In each of seven geographic areas, Bancroft Hunt shows how topography and climate shape a bioregion's shamanic practice. Beginning with the Eskimo-Aleut of the North American Arctic, the chapters move to the Subarctic and Great Lakes, the Northwest Coast, the Southwest, California and the Plains. The author traces the connection between place and culture; for instance, the Subarctic is described as a land of meager or scattered resources which could support only tiny isolate groups except for occasional communal celebrations when weather conditions were favourable: "Spiritual life reflects the uncertainties of Subarctic living. There are few organized cults or associations of shamans, and there is little formal training for anyone who wishes to take up shamanism as a vocation." Nevertheless, and this is something many ethnographers have ignored or been unaware of, "the influence of the shamans is apparent in virtually every activity" (p. 47). Though perhaps physically absent in the Subarctic, the shaman has been a pervasive and immediate force through charms and healing herbs passed on to descendants and through direct interventions often in dreams. Thus shamanism and shamanic dreams join these scattered groups like beads on a necklace in a common spiritual heritage.

Similar connections are made in each chapter, but I will focus on the Arctic which shows, perhaps, the fullest conjunction of shamanic life and the environment. Bancroft Hunt's writing is sensual, even poetic:

The Far North, home to the Eskimo and Aleut of the Arctic coasts, is a world of illusions. Powder snow driven by constant winds, and thick fog raised as a water vapour crosses frozen land masses, create an environment in which things are seen and half seen; where they become both tangible and intangible. There is an ephemeral sense to the landscape: great banks of snow standing tall and solid as mountains can shift or disappear overnight with contrary winds. The Spirits of the Weather, Storm, Wind, Cloud, Snow and Cold play capricious tricks [...] they compete in elemental battles fierce enough to tear the landscape apart and rearrange it and when visibility may be reduced to absolute zero. When vision is restored the world is no longer as it has been, and the Eskimo gazes out over unfamiliar vistas. There are few clear points of reference in a world as impermanent as this (p. 15).

As the background to life in the Arctic is uncertainty, shamans face uncertainty and danger in the spirit world where they may be mutilated or die; or, they may return 
with spiritual mastery. Their peril is the peril the community faces every day but their triumph is to aid their community by placating or diverting spirits whose motives are self-serving; by attending to the social fabric by evoking confessions of wrongdoing from community members, thus defusing anger and resentment which might otherwise have exploded in the long winter night; or by intervening to heal the sick or calm a blizzard.

There is a bibliography for the volume rather than for each chapter and it is not very extensive-certainly it doesn't acknowledge the vast amount of historical and ethnographic writing on the Arctic (and summarized, for example, in Merkur 1992) much of which contains some reference to shamanism. Historical and ethnographic references include a substantial account from Freuchen (three pages out of approximately 18 pages of text) but Freuchen's name doesn't appear in the index or the bibliography which is pretty much limited to only three specifically Arctic sources (Burch, Fitzhugh and Kaplan, and Rasmussen).

In his Introduction, Bancroft Hunt uses the gender-neutral he/she when writing about shamans but he doesn't extend this into the Arctic chapter. Not once is a female shaman mentioned or the female pronoun used. Nor is the problem of translating the gender-neutral Eskimo language into English discussed or even acknowledged, as in this example: "His own spirit-known to the Eskimo as the inua, or soul [...] is nervous and frightened yet must show no sign of weakness which could be taken advantage of" (p. 18). Inua translates as "its person" or "its human being" meaning spiritual inhabitant visualized as a tiny human being - male or female.

The chapter gives the distinct impression that all Arctic shamans were and are male. In the historical literature, we might forgive this male bias because many of the early visitors to the North were male, but this doesn't mean there weren't female shamans as a broader reading of the literature would have revealed, as would fieldwork by anyone with a sensitivity to the lack of recognition of women shamans in all regions, but especially in the Arctic. The first shaman I ever knew about was pointed out to me in Rankin in the 1960s - a wizened old woman covered in tattoos, she lived alone in a tent on the beach and was looked at with a mixture of awe and fear in a community where the Anglican and Catholic churches were strong and patriarchal.

Kroeber (1900: 307), as one example of many, points out that "man or woman, old or young" may become angakoq. There are carvings of women shamans, for example one by Nancy Pukingnrak of Baker Lake dated 1976 and illustrated in Blodgett (1979). Rasmussen, one of Bancroft Hunt's few bibliographic entries, mentions a number of women shamans - the Iglulik shaman Uvavnuk who became a great shaman when the spirit of a meteor entered her; the young woman shaman Kinâlik who was "shot" and then came back to life; and the woman shaman Utsugpagläk who wore a piece of a shaman belt as an amulet to give her son shamanic powers. Both of these last two women shamans were Caribou Eskimos. Stefansson (1913) reported that women were among the greatest shamans known to him. One wonders why these and other examples weren't picked up on. Spirits, too, may be female though Bancroft Hunt refers to a spirit as "it" throughout. 
Other generalizations seem ill-considered. The reader gets no sense that Bancroft Hunt is reconstructing "Arctic" characteristics from a literature that was often site and date-specific - there are unfortunate gaps in information about provenance and time period. There are other problems in the chapter that will lead an informed reader to question the scholarship of the book. "Eskimo" is used problematically without any explanation of its historical or ethnographic derivation, or any mention of emic names used in the past or today. Perhaps this was an editing decision to assist with readability by cutting down on footnotes. In fact, there are no footnotes or endnotes for the chapters individually or for the book as a whole. We are given no sources for such things as stories about shamans. Are they from historical accounts? Are they first-hand accounts? Are they archival? Are they told in Arctic communities today? The brief (2 1/2 pages) concluding chapter points out shamanism's "permanent presence and significance today" (p. 225) but since the ethnographic present is used throughout, we get little sense of the relationship between past and current shamanic practice amongst North American Arctic peoples today.

Annotations for the illustrations are inconsistent, leaving the reader to wonder about whether they derive from the author's own research or whether they were taken directly from museum catalogues. Some need editing - an oblong wooden dish holding an Arctic shaman's objects is labeled as a "bowl." A page of acknowledgments lists the sources of the extensive illustrations compiled from collections in the United States and Canada, the British Museum and the Peter the Great Museum of Anthropology and Ethnology. It includes two of the author's own illustrations which are landscape shots in the Plains chapter. Other landscape photographs that introduce and illustrate each chapter have been well-chosen but they come from the National Parks Service or other archive.

There is no question that this is an "impressive" book as it has been called in the lay press (Todd 2003). There is much to learn from its content and Bancroft Hunt's interpretation of shamanism in North America. It is also important for the due emphasis that Bancroft Hunt accords shamanism and shamanic ways of knowing. The informed reader, however, will be left wondering about the author's direct experience of his subject matter.

\section{References}

\section{BLODGETT, Jean}

1979 The coming and going of the shaman: Eskimo shamanism and art, Exhibition catalogue, Winnipeg, Winnipeg Art Gallery.

KROEBER, Alfred L.

1900 The Eskimo of Smith Sound, Bulletin of the American Museum of National History, 12(31): 265-327. 
MERKUR, Dan

1992 Becoming Half-Hidden: Shamanism and Initiation Among the Inuit, New York, Garland Publishing.

STEFANSSON, Vilhjalmur

1913 My Life with the Eskimo, New York, MacMillan.

TODD, Douglas

2003 On the Comeback Trail, The Vancouver Sun, January 24: A15.

Marilyn Walker Dept. of Anthropology Mount Allison University Sackville, New Brunswick E4L 1A7

Canada mwalker@mta.ca

\section{CHRISTENSEN, Neil Blair}

2003 Inuit in Cyberspace - Embedding Offline Identities Online, Copenhagen, Museum and Tusculanum Press and University of Copenhagen, 152 pages.

Neil Blair Christensen ${ }^{1}$ has conducted an on-line field work on the use of cyberspace partly through a net survey from March till June 1998 in Alaska, Canada and Greenland, partly through nine months of e-mail correspondence with participants from the Aleutian Islands across Arctic Canada to East Greenland. One hundred and thirty-one persons out of about 1,000 potential participants across the Arctic responded to the survey and out of these, 70 persons supplied their e-mail address. Moreover, Christensen has analysed more than 300 Arctic Web sites. Christensen has included an appendix with results from the questionnaire which has 20 standardised questions and two open questions. Looking at some examples from this list, 57\% males and $43 \%$ females responded to the survey, mostly from Canada (37\%) and Alaska (35\%) - 22\% of the respondents came from Greenland, $6 \%$ from "other places." It also appears that $83 \%$ of the respondents use the Internet for e-mail correspondence and for surfing, and that $80 \%$ of the respondents connect to countries outside the Arctic (p. 113). Even so, more than half of the respondents think that the Internet will bring people in the entire Arctic closer together (p. 115). On the question whether information through the Internet brings the world into the Arctic or the other way round, $71 \%$ of the respondents think it works both ways. Moreover, $71 \%$ of the respondents think that cultural contents are important on Arctic Web pages.

The author has a MA degree in Eskimology and is a publishing manager for Blackwell Publishing. The title of his book shares the same title as his MA thesis from 1999 at the Department of Eskimology at the University of Copenhagen. His research field has included topics like identity, culture, distance education and the Internet. His origin is of mixed Danish-Jamaican parentage; born in Ittoqqortoormiit on the east coast of Greenland in 1971 and having lived in different places in Greenland from north to south until the age of 8 , thereafter he moved to Denmark with his family (p. 25). 